\title{
Phenomenon of osteocyte lacunar mineralization: indicator of former osteocyte death and a novel marker of impaired bone quality?
}

\author{
Petar Milovanovic ${ }^{1,2}$ and Björn Busse ${ }^{1}$ \\ 1Department of Osteology and Biomechanics, University Medical Center Hamburg-Eppendorf, Hamburg, Germany \\ 'Laboratory for Anthropology and Skeletal Biology, Institute of Anatomy, Faculty of Medicine, University of Belgrade, Belgrade, Serbia \\ Correspondence should be addressed to B Busse: b.busse@uke.uni-hamburg.de
}

\begin{abstract}
An increasing number of patients worldwide suffer from bone fractures that occur after low intensity trauma. Such fragility fractures are usually associated with advanced age and osteoporosis but also with long-term immobilization, corticosteroid therapy, diabetes mellitus, and other endocrine disorders. It is important to understand the skeletal origins of increased bone fragility in these conditions for preventive and therapeutic strategies to combat one of the most common health problems of the aged population. This review summarizes current knowledge pertaining to the phenomenon of micropetrosis (osteocyte lacunar mineralization). As an indicator of former osteocyte death, micropetrosis is more common in aged bone and osteoporotic bone. Considering that the number of mineralized osteocyte lacunae per bone area can distinguish healthy, untreated osteoporotic and bisphosphonate-treated osteoporotic patients, it could be regarded as a novel structural marker of impaired bone quality. Further research is needed to clarify the mechanism of lacunar mineralization and to explore whether it could be an additional target for preventing or treating bone fragility related to aging and various endocrine diseases.
\end{abstract}

\author{
Key Words \\ - bone \\ - osteoporosis \\ - micropetrosis \\ - bone fragility \\ - bisphosphonates
}

\section{Introduction}

From a medical materials science viewpoint, bone is a remarkably hierarchically organized nanostructured material with a peculiar organization of mineral and organic phases $(1,2,3)$. Bone is subject to various mechanical demands and must withstand loads, while bone also shields organs and serves as a means for mineral homeostasis $(4,5)$. Bone is also a living and dynamic tissue, and the bone matrix houses numerous living bone cells $(6,7)$. Therefore, in contrast to most materials, human bone has a remarkable ability to adapt its volume and structure to the local $(8,9)$ and global needs of the organism (10). Moreover, human bone has the ability to repair damage that was induced during repetitive loading by renewing packets of bone tissue (11). Osteocytes, the most numerous bone cells that are strategically distributed through entire bone matrix (7) exhibit extraordinary behavior in bone renewal processes.

During aging and in some diseases, bone loses its ability to successfully withstand mechanical loads (12), exhibiting diminished ability to successfully adapt to sudden and repetitive mechanical situations (demands) $(13,14)$. Its capacity for damage repair also reduces, and targeted bone renewal drastically declines $(15,16)$. The latter might contribute to increased bone fragility and, subsequently, fracture risk increases underpinning major problems in the elderly population (17). In the year 2000 alone, 9 million osteoporotic fractures occurred worldwide, and epidemiological trends suggest further increases in bone fracture burden in aging populations $(18,19)$. However, a deeper understanding of the origins and mechanisms of increased bone fragility is essential for

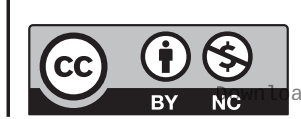

This work is licensed under a Creative Commons Attribution-NonCommercial 4.0 International License. ded from Bioscientifica.com at 04/26/2023 10:14:23AM 
the development of preventive and therapeutic strategies to combat one of the most common health problems in aged individuals worldwide.

\section{Role of osteocytes in bone adaptation}

Currently, many bone properties are considered to be controlled or mediated by osteocytes (20). Osteocytes are primarily considered sensors of mechanical stress, which is generally based on: (i) their strategic distribution throughout the bone matrix, a network that provides intercellular communication, and (ii) their ability to respond to mechanical stimuli in vitro by producing biochemical signals that are capable of affecting other bone cells $(21,22,23,24)$. Although osteoblasts can sense and respond to loads, the osteocyte network is a necessary 'antenna' to detect signals and bone mechanosensory potential (25). In addition, in vitro studies have demonstrated that osteocytes are the most mechanoresponsive bone cells, particularly to fluid flow $(21,26)$. There is growing data on mechanotransduction pathways (for a review see: (27)), for example, on how bone (osteocytes) detects mechanical signals and converts these signals into biochemical signals that can affect neighboring cells. The relationship between osteocytes and other bone cells is intriguing, given that the same osteocytes can exert both positive and negative regulation on osteoblasts and osteoclasts (28). However, since an osteocyte receives complex information (not only mechanical but also biochemical via various cytokines and signaling molecules), the sum of the stimuli determines whether osteocytes stimulate or inhibit bone formation or resorption (28). In the case of loading, increased fluid flow stimulates osteocytes to produce biochemical signals that inhibit osteoclast formation and resorption $(29,30)$ and promote osteoblast proliferation and differentiation (26), with a net bone-forming effect. Nitric oxide (NO) is one of the biochemical markers of the osteocyte response to mechanical loading $(22,24,31)$ that is known to induce bone formation $(32,33)$ and promote osteocyte survival (34). In cases of insufficient loading, the lack of NO production leads to osteocyte apoptosis, and bone resorption is initiated, which adapts the bone structure to low-load conditions.

\section{Osteocyte death}

The lifetime of osteocytes is variable, but unlike other bone cells, osteocytes are capable of exceptional longevity; if a bone region remains unaffected by remodeling long enough, osteocytes can even live for several decades (35). Since the initial report by Frost (36), numerous studies visualized or quantified osteocyte death in various conditions $(37,38,39,40,41,42,43,44)$. Osteocyte death is, in general, dependent on patient age and tissue age, but premature osteocyte death also occurs due to hormonal reasons, such as estrogen deficiency or corticosteroid excess $(38,39,45)$. Moreover, osteocyte death may be caused by mechanical factors $(36,46)$, but the relationship between mechanical loading and osteocyte survival is actually biphasic (47). Namely, for survival, osteocytes need constant 'stimulation', for example, a certain level of strain and/or fluid flow is necessary. For example, Noble et al. (47) reported that physiological strain decreased the number of apoptotic cells and even increased the number of young osteocytes. It has been shown that loadinduced fluid flow inhibits osteocyte apoptosis via NO production (34). Strain and fluid flow promote osteocyte viability possibly by facilitating antiapoptotic pathways in osteocytes $(34,47)$, and fluid flow enhances molecular transport and nutrient supply to keep osteocytes healthy (48). In addition to insufficient strain, such as during weightlessness (44) or long-term immobilization (49), too much strain is also dangerous and osteocytes can be considered to 'overdose'. Specifically, excessive strain was found to increase the number of apoptotic osteocytes (47). It is not exactly clear why osteocytes die under high strain conditions; however, Noble et al. (47) suggested that either pathologically high strain launches apoptosis machinery within osteocytes or matrix damage is responsible for cell death.

\section{Mineralization of osteocyte lacunae}

Based on basic fuchsin-stained bone samples observed under bright field microscopy, Frost noticed unstained lacunae and canaliculi and suggested that they had been filled with mineral, for which he coined the term 'micropetrosis' (46).

Boyde and colleagues used backscattered electron microscopy and observed mineralized lacunae in human mandibles, especially in aged individuals, but also in calvarial bones, long bones near metal implants, and grafted bone $(50,51,52)$. They showed that such lacunae can express various degrees of mineralization and may occupy extensive bone areas with higher mineralization levels than the neighboring osteons (51). An ultrastructural study that applied scanning and transmission electron

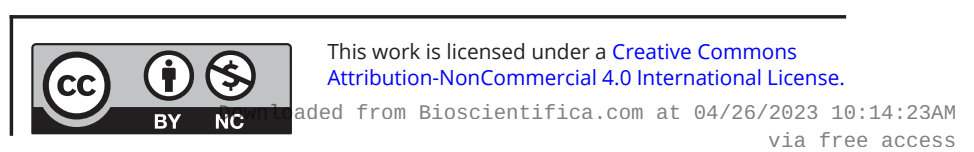


microscopy of mineralized lacunae showed apoptotic remnants of osteocytes within the mineral matter (53) and labeled such lacunae as 'living fossils' that preserve the fragments of a previous cell (53).

The first quantitative analysis of mineralized lacunae (Fig. 1) in cortical bone from human femoral diaphysis in young (20-40 years) and aged ( $>80$ years) individuals of both sexes was based on backscattered electron microscopy and showed a marked age-related increase in mineralized lacunae per bone area (54) along with a notable reduction in normal appearing osteocyte lacunae (54). While these findings confirmed that with aging many osteocytes die, we suggest that if the bone areas containing dead osteocytes are not remodeled, such lacunae would become occluded with a high mineral content, as verified via energy dispersive $\mathrm{X}$ ray spectroscopy (54). The endocortical compartment tended to have a higher number of mineralized lacunae per bone area than the pericortical compartment in aged individuals $(1,54)$. Considering the concomitant lower overall mineralization of the pericortical compartment (1), such findings may be explained by the increased apposition of fresh bone to the periosteal surface during a person's lifetime $(55,56)$.

Our backscattered electron microscopy data on femoral cortical bone in young females, healthy aged females, females with untreated osteoporosis, and females with bisphosphonate-treated (BP) osteoporosis showed that in addition to the observed age-related increase in the number of mineralized lacunae per bone area, lacunar occlusion further increased due to osteoporosis (1).
Namely, aged females with untreated osteoporosis displayed nearly twice as many mineralized lacunae per bone area as age-matched healthy women (1). However, the osteoporosis patients who underwent long-term bisphosphonate treatment exhibited a reduced number of lacunar occlusions, which was comparable to the prevalence in healthy aged individuals (1). Obviously, there is a consistent positive influence of bisphosphonates on osteocyte viability, reflected by a reduced number of mineralized lacunae, compared with individuals with untreated osteoporosis (1). This finding is compatible with recent cell culture and animal studies revealing osteocyte antiapoptotic effects of bisphosphonates (BPs) $(57,58)$.

It is not yet clear whether there is any difference in terms of mineralization starting point, for example, whether mineral occlusion starts in lacunae or in canaliculi. Indeed, canaliculi can be mineralized even before the lacunae are occluded with mineral substance (51), which is an important sign of aged bone (6). Namely, our study on acid-etched resin embedded mid-cortical bone from the proximal femoral diaphysis showed a significant reduction in the number of canaliculi per osteocyte lacunae in aged individuals compared with young individuals (6). As mid-cortical bone is difficult to access during remodeling due to its large distance from bone surfaces $(59,60)$, it bears signs of aged tissue, especially in aged individuals, evidenced by a higher calcium to phosphorus ratio according to EDX and increased calcium concentration according to quantitative backscattered electron imaging (6). Consequently, the decrease in the number of canaliculi leads to a prominent
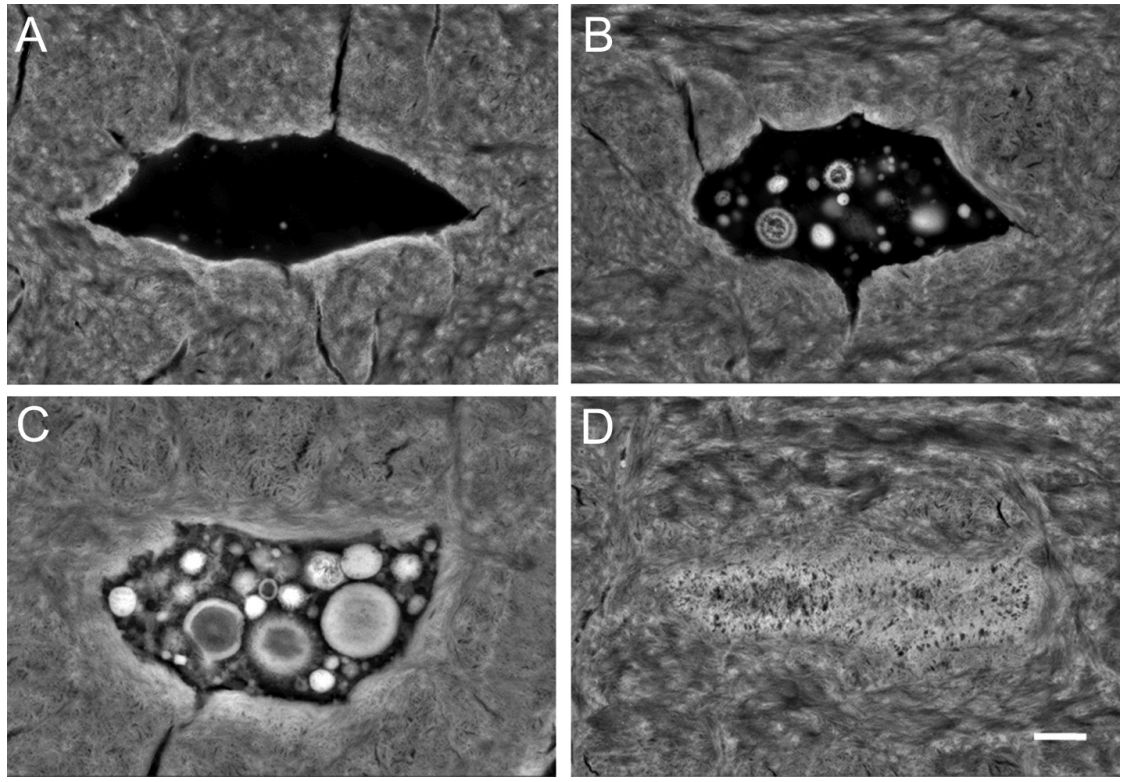

Figure 1

The process of lacunar mineralization (micropetrosis) passes through different stages from normal appearing osteocyte lacuna (A) via partly filled lacuna with clearly identifiable calcified nanospherites ( $B$ and $C$ ) and finally complete occlusion of the lacuna with mineral (D). (Backscattered electron microscopy images, Scale bar $1 \mu \mathrm{m})$. https://ec.bioscientifica.com https://doi.org/10.1530/EC-19-0531 (c) 2020 The authors Published by Bioscientifica Ltd

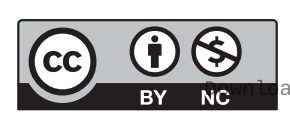

This work is licensed under a Creative Commons Attribution-NonCommercial 4.0 International License. ded from Bioscientifica.com at 04/26/2023 10:14:23AM 
reduction in connections between osteocyte lacunae within mid-cortical osteons (6). Moreover, we have observed that, in young bone, canaliculi frequently cross the cement lines and often have connections with interstitial bone osteocyte lacunae; we believe that these connections may be essential for the viability of interstitial osteocytes by providing them with nutrients through canalicular fluid flow and by providing appropriate mechanical stimulation for their survival (6). Thus, interstitial osteocytes can still be part of a dynamic and mechanosensitive lacunocanalicular system (6). However, in aged individuals, we found a dramatic reduction in canalicular connections between osteonal and interstitial lacunae, which could explain why interstitial regions are particularly rich in dead osteocytes and represent a preferential location for the development of mineralized lacunae $(1,54)$. Indeed, one of the reasons for the lower number of canaliculi is their mineralization, while there is a possibility that even new osteocytes initially form fewer dendrites in aged bone. In future studies, it would be interesting to compare the osteocytes in the bone packets of similar tissue age in young and aged individuals to clarify whether individual's age or tissue age has a decisive role in loss of dendrites. The results from a recent animal study on osteocytes isolated from young and aged mice showed lower number of dendrites in aged osteocytes (61), while study using confocal microscopy reported a reduced dendritic number in aged mice (62).

Despite the observations that mineralized nanospherites (Fig. 1) appear at both lacunae and canaliculi (63), there is some evidence that canaliculi are first to be occluded by minerals. It is unknown whether this is always a part of the same phenomenon of lacunar mineralization, although canalicular reduction is associated with tissue age-related increases in calcium content in the surrounding bone (6). Likewise, the number of mineralized osteocyte lacunae per osteon bone area is positively correlated with both osteonal calcium content and cement line calcium content, two indicators of tissue age (64). Our acid-etching study showed three states of the peripheral canaliculi in mid-cortical osteons: preserved canaliculi that fully cross the cement line to establish an external 'routing' of osteons; canaliculi interrupted at the cement line; and a complete lack of visible canaliculi on the peripheral side of the outermost osteonal lacunae, as the mineral that had filled them was removed by acid while the lacuna remained patent as it was filled with polymethylmethacrylate (6). Canalicular mineralization certainly indicates a loss of dendritic processes, while dendrite numbers were shown to be inversely related to age $(61,62)$.

\section{Mineralized osteocyte lacunae as indicators of impaired bone quality}

Our quantitative data on osteocyte lacunae revealed that the amount of mineralized osteocyte lacunae is associated with differential bone quality, as bone with different mechanical properties (young, aged, untreated osteoporosis, BP-treated osteoporosis) can be distinguished based on the number of mineralized lacunae per bone area (1). Namely, mineralized lacunae are related to the age of the individual, and the occurrence and density of mineralized lacunae are significantly higher in untreated osteoporotic patients than in healthy aged individuals and BP-treated osteoporotic patients (1).

We recently demonstrated a decreased osteocyte lacunar number per bone area of the femoral neck's periosteal cortex in aged females who sustained hip fracture compared with aged-matched healthy controls (65). However, while there is a general agreement regarding osteocyte depletion with aging $(66,67,68,69,70,71$, $72,73,74)$, data in the literature on osteocyte lacunar density in iliac, vertebral, and femoral trabecular bone compartments of osteoporotic patients are inconsistent and sometimes contradictory $(75,76,77,78,79)$. Our study on femoral diaphysis did not show a significant difference in lacunar density between three different groups of elderly women (healthy aged, untreated osteoporosis, BP-treated osteoporosis), while young cases presented with higher osteocyte lacunar density, although without reaching significance level (1). Therefore, taken together, our findings suggest that differences in mineralized lacunae are better than osteocyte lacunar density alone in discriminating among different groups of individuals.

Currently, the main mechanisms by which mineralized lacunae may promote bone fragility can be considered as follows (Fig. 2):

- Mineralized lacunae are 'plugs' in the osteocyte lacunocanalicular network that cause localized dysfunction of the network (63) in terms of blocked fluid flow:

Certainly, this would block nutrient supply to other osteocytes, especially interstitial osteocytes, favoring more cell death. As fluid flow is also essential for mechanosensitivity $(48,80,81)$, it is apparent that obstacles to fluid flow compromise the ability of bone

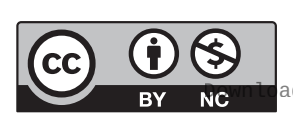

This work is licensed under a Creative Commons Attribution-NonCommercial 4.0 International License. ded from Bioscientifica.com at 04/26/2023 10:14:23AM via free access 


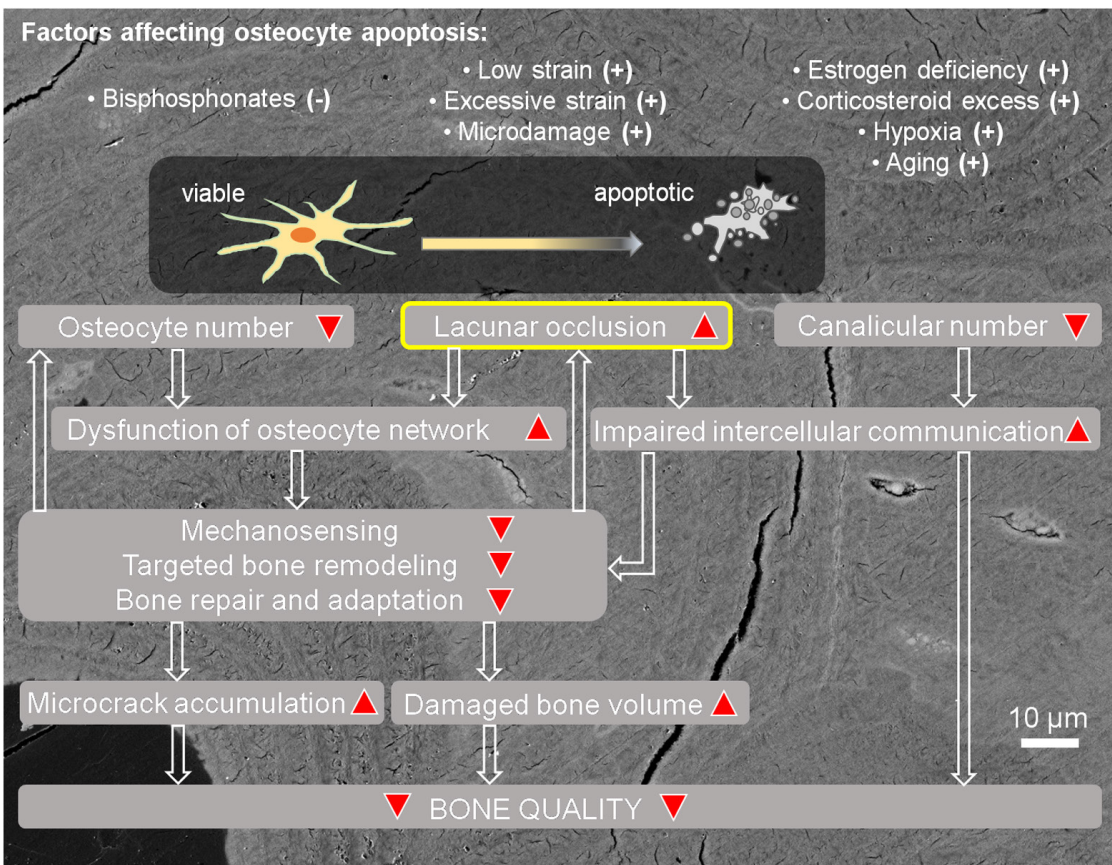

\section{Figure 2}

Schematic representation of the effects of accelerated osteocyte death and micropetrosis on bone quality. to sense and appropriately respond to mechanical signals. Localized dysfunction of the osteocyte network may cause local mechanical imbalances, making these areas particularly vulnerable to mechanical loading.

- A lack of viable osteocytes hampers bone mechanosensitivity and delays or reduces the repair of microdamage:

Osteocytes are crucial regulators of bone remodeling. In particular, osteocytes are the main source of signals needed for targeted repair of damaged areas. Here, osteocyte death may result in a loss of antiresorptive signals or the secretion of proresorptive signals $(11,82)$. However, it is likely that a certain density of osteocytes is needed to detect damage and launch remodeling processes (16); in this sense, extensive loss of viable osteocytes in a certain area would leave significant amounts of bone tissue with unprocessed damage which further accumulates and hampers bone quality.

Considering the accumulation of such mineral-rich spots and delayed/hampered remodeling that leads to increased calcium content (increased tissue age), these particular tissue areas increase their brittleness and are more prone to microcracking $(54,83)$. More advanced tissue age is associated with increased size of mineral crystals $(13,65,84,85,86,87)$, mostly via crystals' coalescence, which decreases interfibrillar sliding and thereby reduces toughness at the level of mineralized collagen fibrils $(65,88,89,90,91,92)$. Older tissue presents altered collagen characteristics as well, which may be another important hallmark of increased bone fragility $(83,90,93,94)$. Although detrimental in skeletal sites subject to load bearing, excessive and early micropetrosis occurring in the auditory ossicles (sites with low mechanical loads) could be an adaptive response conserving the architecture of the auditory ossicles and ensuring stable sound transmission from early childhood throughout life (95).

\section{Mechanisms of lacunar mineralization}

There is a general agreement that lacunar mineralization is associated with osteocyte apoptosis $(52,54,77)$. However, understanding the precise mechanism of lacunar mineralization remains of particular importance to the bone research community. Lacunar occlusion can be regarded as a passive phenomenon, an active mineralization phenomenon, or a combination of the two.

The theory behind the passive (spontaneous) mineralization mechanism is based on the current belief that osteocytes are capable of preserving an unmineralized pericellular space by inhibiting mineralization (96, 97) to allow fluid flow-based mechanosensitivity and nutrient transfer (98). For this goal, osteocytes produce crystallization and mineralization inhibitors (SIBLING proteins such as osteopontin and MEPE, fetuin-A or tethering elements' component - perlecan) as well as enzymes for active digestion of their direct surroundings

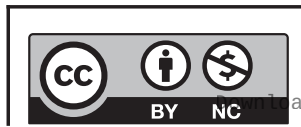

This work is licensed under a Creative Commons Attribution-NonCommercial 4.0 International License. ded from Bioscientifica.com at 04/26/2023 10:14:23AM 
(such as matrix metalloproteinases) (96, 99, 100, 101) to prevent spontaneous calcium and phosphorus precipitation around the cell $(102,103)$ and are even able to dissolve bone minerals, as observed in lactation (10). Additional molecules involved in the process may be locally produced FGF23 and osteopontin, as animal studies suggested that increased local production of FGF23 by osteocytes reduces activity of alkaline phosphatase, leading to increased levels of pyrophosphate, a known mineralization inhibitor (104). However, following osteocyte death, the lack of crystallization inhibitors allows spontaneous mineralization of the lacuna and canaliculi, given the normally available calcium in the extracellular space. Our rigorous characterization of mineralized lacunae revealed that its mineral composition significantly differs from that of normal bone matrix (63). The higher mineral-to-matrix ratio and the markedly reduced collagen content suggest that there is no organic deposition in the lacuna that is being mineralized, emphasizing how lacunar mineralization processes differ from the process of normal bone matrix formation, suggesting the existence of a passive mineralization process (63).

However, we believe that calcification is not just a passive phenomenon but rather an active biological solution that is employed when dying cells cannot be taken up by phagocytosis, as in the case of mineralized tissue. It should also be noted that some other initially noncalcified tissues (such as vascular smooth muscle, valves, and cartilage $(105,106,107))$ may show mineralization processes that are analogous to lacunar mineralization, suggesting that mineral deposition in osteocyte lacunae is just one example of a more widely ranging type of biological mineralization.
Namely, our recent study revealed that mineralized lacunae consist of a various number (up to more than a hundred) of mineralized spherical entities that we labeled nanospherites, based on their average diameter of $655 \pm 448 \mathrm{~nm}$ (63). Considering the shape and size of the nanospherites, as well as the fact that apoptotic osteocyte material rarely disappears from the lacuna, the nanospherites may originate from apoptotic bodies; however, they can also originate from matrix vesicles released from still living osteocytes (63). The cellular origin of the nanospherites is also corroborated by the higher magnesium content in nanospherites than in bone matrix $(63,108)$, as magnesium is an important intracellular ion (109). Therefore, the question regarding the active components of lacunar mineralization remains unanswered. Previous studies of cartilage and vascular smooth muscle have suggested that both matrix vesicles and apoptotic bodies have the specific ability to actively concentrate calcium $(106,107,110,111)$ owing to the presence of several calcium-binding molecules, such as phosphatidyl-serine at the surface of the membrane $(106,112)$. In this context, osteocytes may be initiators of lacunar mineralization, which is complemented also by spontaneous precipitation of calcium between the nanospherites. Finally, our data suggest that mineral nanospherites grow by adding new minerals and eventually fuse with each other, thus leading to complete mineral occlusion of the lacuna (63).

\section{Hormones and osteocyte viability}

Postmenopausal osteoporosis is associated with estrogen deficiency. Our previous studies in human bone showed

Table 1 Factors affecting osteocyte death and viability.

\begin{tabular}{l}
\hline Factors affecting osteocyte death and viability \\
\hline Factors favoring osteocyte death \\
Aging \\
Low mechanical strain (e.g. immobilization or weightlessness) \\
Excessive mechanical strain, microcracking \\
Estrogen deficiency (e.g. postmenopause or treatment with GnRH) \\
Glucocorticoid excess (endogenous or exogenous) \\
Vitamin D deficiency \\
Vitamin D receptor deficiency \\
Factors promoting osteocytes viability \\
Normal mechanical loading (load-induced fluid flow in lacunocanalicular network) \\
Intermittent administration of PTH(1-34) \\
Bisphosphonates treatment \\
Nitric oxide (NO)
\end{tabular}

\begin{tabular}{c}
\hline References \\
\hline $1,16,54$ \\
$44,47,49$ \\
16,47 \\
38,39 \\
$42,45,113$ \\
83,118 \\
118 \\
34,47 \\
$115,116,117$ \\
$1,57,58$ \\
34
\end{tabular}


higher number of mineralized lacunae in postmenopausal compared to premenopausal women $(1,54)$. While aging itself likely also plays a role, estrogen deficiency is certainly an important contributor to increased osteocyte apoptosis. Experimental data supporting the role of estrogen in osteocyte viability are available from studies on human bone (e.g. estrogen withdrawal due to gonadotropinreleasing hormone administration was linked to increased osteocyte apoptosis in iliac crest biopsies (38)) as well as from animal studies (ovariectomy increases osteocyte apoptosis in rats, which can be rescued by administration of estrogen (39)).

Apart from postmenopausal estrogen deficiency, there is no direct data on the amounts of mineralized lacunae in conditions with a changed hormonal status. Nevertheless, a number of observational or experimental studies showed the effects of hormones on osteocyte apoptosis and viability (Table 1). Numerous articles reported that glucocorticoid excess increases osteocyte apoptosis both in human bone and animal models $(42,45,113)$. However, proapoptotic effects are not the only negative impact that glucocorticoids have on osteocytes, since there is experimental data showing that glucocorticoids suppress osteocytic expression of matrix metalloproteinases and consequently impair perilacunar remodeling with degeneration of the lacunocanalicular network and matrix hypermineralization (114). Unlike glucocorticoids, PTH(1-34) is generally linked with prosurvival signals for osteocytes (115), and it was shown that intermittent administration of PTH can prevent osteocyte apoptosis caused by glucocorticoid excess (116) or radiotherapy (117). Vitamin D was also found to affect the viability and characteristics of osteocytes. Namely, vitamin D deficiency was accompanied by reduced osteocyte numbers, increased osteocyte apoptosis, and decreased osteocytic connectivity; while vitamin D receptor deficiency also reduced viable osteocyte numbers (118).

\section{Conclusion}

Mineral nanospherites should be investigated more closely to determine their impact on mineral homeostasis. In particular, experimental studies would be beneficial for further clarification of the process of lacunar mineralization, including the conditions of endogenous or exogenous hormonal excess or deficiencies. A better understanding of the lacunar mineralization phenomenon may potentially be explored as another target for preventing or treating bone fragility.

\section{Declaration of interest}

The authors declare that there is no conflict of interest that could be perceived as prejudicing the impartiality of this review.

\section{Funding}

This work was supported by the German Research Community (DFG) under grant no. BU 2562/3-1, Alexander von Humboldt Foundation, South-EastEurope Cooperation of the University Medical Center Hamburg-Eppendorf, and the Science Fund of the Republic of Serbia.

\section{References}

1 Milovanovic P, Zimmermann EA, Riedel C, vom Scheidt A, Herzog L, Krause M, Djonic D, Djuric M, Püschel K, Amling M, et al. Multi-level characterization of human femoral cortices and their underlying osteocyte network reveal trends in quality of young, aged, osteoporotic and antiresorptive-treated bone. Biomaterials 201545 46-55. (https://doi.org/10.1016/j.biomaterials.2014.12.024)

2 Zimmermann EA, Busse B \& Ritchie RO. The fracture mechanics of human bone: influence of disease and treatment. BoneKEy Reports 20154 743. (https://doi.org/10.1038/bonekey.2015.112)

3 Fantner GE, Rabinovych O, Schitter G, Thurner P, Kindt JH, Finch MM, Weaver JC, Golde LS, Morse DE, Lipman EA, et al. Hierarchical interconnections in the nano-composite material bone: fibrillar cross-links resist fracture on several length scales. Composites Science and Technology 200666 1205-1211. (https://doi. org/10.1016/j.compscitech.2005.10.005)

4 Seeman E. Mineral Homeostasis. Primer on the Metabolic Bone Diseases and Disorders of Mineral Metabolism, pp. 171-172. Hoboken, NJ, USA: John Wiley \& Sons, Inc., 2013. (https://doi. org/10.1002/9781118453926.part3)

5 Currey JD. Bones: Structure and Mechanics. Princeton, NJ, USA: Princeton University Press, 2002.

6 Milovanovic P, Zimmermann EA, Hahn M, Djonic D, Püschel K, Djuric M, Amling M \& Busse B. Osteocytic canalicular networks: morphological implications for altered mechanosensitivity. ACS Nano 20137 7542-7551. (https://doi.org/10.1021/nn401360u)

7 Noble BS \& Reeve J. Osteocyte function, osteocyte death and bone fracture resistance. Molecular and Cellular Endocrinology 2000159 7-13. (https://doi.org/10.1016/s0303-7207(99)00174-4)

8 Djurić M, Milovanović P, Djonić D, Minić A \& Hahn M. Morphological characteristics of the developing proximal femur: a biomechanical perspective. Srpski Arhiv za Celokupno Lekarstvo 2012 140 738-745. (https://doi.org/10.2298/SARH1212738D)

9 Turner CH. Skeletal adaptation to mechanical loading. Clinical Reviews in Bone and Mineral Metabolism 20075 181-194. (https://doi. org/10.1007/s12018-008-9010-x)

10 Wysolmerski JJ. Osteocytes remove and replace perilacunar mineral during reproductive cycles. Bone 201354 230-236. (https://doi. org/10.1016/j.bone.2013.01.025)

11 Taylor D, Hazenberg JG \& Lee TC. Living with cracks: damage and repair in human bone. Nature Materials 20076 263-268. (https://doi. org/10.1038/nmat1866)

12 Cole ZA, Dennison EM \& Cooper C. Osteoporosis epidemiology update. Current Rheumatology Reports 200810 92-96. (https://doi. org/10.1007/s11926-008-0017-6)

13 Milovanovic P, Potocnik J, Djonic D, Nikolic S, Zivkovic V, Djuric M \& Rakocevic Z. Age-related deterioration in trabecular bone mechanical properties at material level: nanoindentation study of the femoral neck in women by using AFM. Experimental Gerontology 201247 154-159. (https://doi.org/10.1016/j.exger.2011.11.011)

14 Milovanovic P, Djonic D, Marshall RP, Hahn M, Nikolic S, Zivkovic V, Amling M \& Djuric M. Micro-structural basis for particular

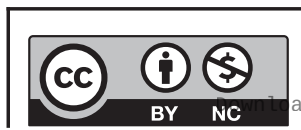

This work is licensed under a Creative Commons Attribution-NonCommercial 4.0 International License. ded from Bioscientifica.com at 04/26/2023 10:14:23AM 
vulnerability of the superolateral neck trabecular bone in the postmenopausal women with hip fractures. Bone 201250 63-68. (https://doi.org/10.1016/j.bone.2011.09.044)

15 Schaffler MB, Choi K \& Milgrom C. Aging and matrix microdamage accumulation in human compact bone. Bone 199517 521-525. (https://doi.org/10.1016/8756-3282(95)00370-3)

16 Vashishth D, Verborgt O, Divine G, Schaffler MB \& Fyhrie DP. Decline in osteocyte lacunar density in human cortical bone is associated with accumulation of microcracks with age. Bone 200026 375-380. (https://doi.org/10.1016/S8756-3282(00)00236-2)

17 Harvey N, Dennison E \& Cooper C The Epidemiology of Osteoporotic Fractures. Primer on the Metabolic Bone Diseases and Disorders of Mineral Metabolism, pp. 348-356. Hoboken, NJ, USA: John Wiley \& Sons, Inc., 2013. (https://doi.org/10.1002/9781118453926.ch40)

18 Kanis JA, Odén A, McCloskey EV, Johansson H, Wahl DA, Cooper C \& IOF Working Group on Epidemiology and Quality of Life. A systematic review of hip fracture incidence and probability of fracture worldwide. Osteoporosis International 201223 2239-2256. (https://doi.org/10.1007/s00198-012-1964-3)

19 Cooper C, Campion G \& Melton LJ. Hip fractures in the elderly: a world-wide projection. Osteoporosis International 19922 285-289. (https://doi.org/10.1007/bf01623184)

20 Schaffler MB, Cheung WY, Majeska R \& Kennedy O. Osteocytes: master orchestrators of bone. Calcified Tissue International 201494 5-24. (https://doi.org/10.1007/s00223-013-9790-y)

21 Klein-Nulend J, van der Plas A, Semeins CM, Ajubi NE, Frangos JA, Nijweide PJ \& Burger EH. Sensitivity of osteocytes to biomechanical stress in vitro. FASEB Journal 19959 441-445. (https://doi. org/10.1096/fasebj.9.5.7896017)

22 McGarry JG, Klein-Nulend J, Mullender MG \& Prendergast PJ. A comparison of strain and fluid shear stress in stimulating bone cell responses - a computational and experimental study. FASEB Journal 200519 482-484. (https://doi.org/10.1096/fj.04-2210fje)

23 Adachi T, Aonuma Y, Tanaka M, Hojo M, Takano-Yamamoto T \& Kamioka H. Calcium response in single osteocytes to locally applied mechanical stimulus: differences in cell process and cell body. Journal of Biomechanics 200942 1989-1995. (https://doi.org/10.1016/j. jbiomech.2009.04.034)

24 Vatsa A, Mizuno D, Smit TH, Schmidt CF, MacKintosh FC \& KleinNulend J. Bio imaging of intracellular NO production in single bone cells after mechanical stimulation. Journal of Bone and Mineral Research 200621 1722-1728. (https://doi.org/10.1359/jbmr.060720)

25 Turner $\mathrm{CH} \&$ Forwood MR. What role does the osteocyte network play in bone adaptation? Bone 199516 283-285. (https://doi org/10.1016/8756-3282(94)00052-2)

26 Vezeridis PS, Semeins CM, Chen Q \& Klein-Nulend J. Osteocytes subjected to pulsating fluid flow regulate osteoblast proliferation and differentiation. Biochemical and Biophysical Research Communications 2006348 1082-1088. (https://doi.org/10.1016/j.bbrc.2006.07.146)

27 Santos A, Bakker AD \& Klein-Nulend J. The role of osteocytes in bone mechanotransduction. Osteoporosis International 200920 1027-1031. (https://doi.org/10.1007/s00198-009-0858-5)

28 Henriksen K, Neutzsky-Wulff AV, Bonewald LF \& Karsdal MA. Local communication on and within bone controls bone remodeling. Bone 200944 1026-1033. (https://doi.org/10.1016/j.bone.2009.03.671)

29 Tan SD, de Vries TJ, Kuijpers-Jagtman AM, Semeins CM, Everts V \& Klein-Nulend J. Osteocytes subjected to fluid flow inhibit osteoclast formation and bone resorption. Bone 200741 745-751. (https://doi. org/10.1016/j.bone.2007.07.019)

30 Kulkarni RN, Bakker AD, Everts V \& Klein-Nulend J. Inhibition of osteoclastogenesis by mechanically loaded osteocytes: involvement of MEPE. Calcified Tissue International 201087 461-468. (https://doi. org/10.1007/s00223-010-9407-7)

31 Vatsa A, Smit TH \& Klein-Nulend J. Extracellular NO signalling from a mechanically stimulated osteocyte. Journal of Biomechanics
200740 (Supplement 1) S89-S95. (https://doi.org/10.1016/j. jbiomech.2007.02.015)

32 Turner CH, Owan I, Jacob DS, McClintock R \& Peacock M. Effects of nitric oxide synthase inhibitors on bone formation in rats. Bone 1997 21 487-490. (https://doi.org/10.1016/s8756-3282(97)00202-0)

33 Chow JWM, Fox SW, Lean JM \& Chambers TJ. Role of nitric oxide and prostaglandins in mechanically induced bone formation. Journal of Bone and Mineral Research 199813 1039-1044. (https://doi. org/10.1359/jbmr.1998.13.6.1039)

34 Tan SD, Bakker AD, Semeins CM, Kuijpers-Jagtman AM \& KleinNulend J. Inhibition of osteocyte apoptosis by fluid flow is mediated by nitric oxide. Biochemical and Biophysical Research Communications 2008369 1150-1154. (https://doi.org/10.1016/j.bbrc.2008.03.007)

35 Manolagas SC \& Parfitt AM. What old means to bone. Trends in Endocrinology and Metabolism 201021 369-374. (https://doi. org/10.1016/j.tem.2010.01.010)

36 Frost HM. In vivo osteocyte death. Journal of Bone and Joint Surgery: American Volume 196042 138-143. (https://doi. org/10.2106/00004623-196042010-00011)

37 Verborgt O, Gibson GJ \& Schaffler MB. Loss of osteocyte integrity in association with microdamage and bone remodeling after fatigue in vivo. Journal of Bone and Mineral Research 200015 60-67. (https://doi. org/10.1359/jbmr.2000.15.1.60)

38 Tomkinson A, Reeve J, Shaw RW \& Noble BS. The death of osteocytes via apoptosis accompanies estrogen withdrawal in human bone. Journal of Clinical Endocrinology and Metabolism 199782 3128-3135. (https://doi.org/10.1210/jcem.82.9.4200)

39 Tomkinson A, Gevers EF, Wit JM, Reeve J \& Noble BS. The role of estrogen in the control of rat osteocyte apoptosis. Journal of Bone and Mineral Research 199813 1243-1250. (https://doi.org/10.1359/ jbmr.1998.13.8.1243)

40 Noble BS, Stevens H, Loveridge N \& Reeve J. Identification of apoptotic changes in osteocytes in normal and pathological human bone. Bone 199720 273-282. (https://doi.org/10.1016/s87563282(96)00365-1)

41 Plotkin LI, Weinstein RS, Parfitt AM, Roberson PK, Manolagas SC $\&$ Bellido T. Prevention of osteocyte and osteoblast apoptosis by bisphosphonates and calcitonin. Journal of Clinical Investigation 1999 104 1363-1374. (https://doi.org/10.1172/JCI6800)

42 Weinstein RS, Nicholas RW \& Manolagas SC. Apoptosis of osteocytes in glucocorticoid-induced osteonecrosis of the hip. Journal of Clinical Endocrinology and Metabolism 200085 2907-2912. (https://doi. org/10.1210/jcem.85.8.6714)

43 Kogianni G, Mann V, Ebetino F, Nuttall M, Nijweide P, Simpson H \& Noble B. Fas/CD95 is associated with glucocorticoid-induced osteocyte apoptosis. Life Sciences 200475 2879-2895. (https://doi. org/10.1016/j.lfs.2004.04.048)

44 Aguirre JI, Plotkin LI, Stewart SA, Weinstein RS, Parfitt AM, Manolagas SC \& Bellido T. Osteocyte apoptosis is induced by weightlessness in mice and precedes osteoclast recruitment and bone loss. Journal of Bone and Mineral Research 200621 605-615. (https:// doi.org/10.1359/jbmr.060107)

45 O’Brien CA, Jia D, Plotkin LI, Bellido T, Powers CC, Stewart SA Manolagas SC \& Weinstein RS. Glucocorticoids act directly on osteoblasts and osteocytes to induce their apoptosis and reduce bone formation and strength. Endocrinology 2004145 1835-1841. (https:// doi.org/10.1210/en.2003-0990)

46 Frost HM. Micropetrosis. Journal of Bone and Joint Surgery. American Volume 196042 144-150. (https://doi.org/10.2106/00004623196042010-00012)

47 Noble BS, Peet N, Stevens HY, Brabbs A, Mosley JR, Reilly GC, Reeve J, Skerry TM \& Lanyon LE. Mechanical loading: biphasic osteocyte survival and targeting of osteoclasts for bone destruction in rat cortical bone. American Journal of Physiology: Cell Physiology 2003 284 C934-C943. (https://doi.org/10.1152/ajpcell.00234.2002) https://ec.bioscientifica.com https://doi.org/10.1530/EC-19-0531
This work is licensed under a Creative Commons Attribution-NonCommercial 4.0 International License. ded from Bioscientifica.com at 04/26/2023 10:14:23AM 
48 Knothe Tate ML, Steck R, Forwood MR \& Niederer P. In vivo demonstration of load-induced fluid flow in the rat tibia and its potential implications for processes associated with functional adaptation. Journal of Experimental Biology 2000203 2737-2745.

49 Rolvien T, Milovanovic P, Schmidt FN, von Kroge S, Wölfel EM, Krause M, Wulff B, Püschel K, Ritchie RO, Amling M, et al. Long-term immobilization in elderly females causes a specific pattern of cortical bone and osteocyte deterioration different from postmenopausal osteoporosis. Journal of Bone and Mineral Research 2020 [epub]. (https://doi.org/10.1002/jbmr.3970)

50 Boyde A, Hendel P, Hendel R, Maconnachie E \& Jones SJ. Human cranial bone structure and the healing of cranial bone grafts: a study using backscattered electron imaging and confocal microscopy. Anatomy and Embryology 1990181 235-251. (https://doi. org/10.1007/bf00174618)

51 Kingsmill VJ \& Boyde A. Mineralisation density of human mandibular bone: quantitative backscattered electron image analysis. Journal of Anatomy 1998192 245-256. (https://doi.org/10.1046/ j.1469-7580.1998.19220245.x)

52 Boyde A. The real response of bone to exercise. Journal of Anatomy 2003203 173-189. (https://doi.org/10.1046/j.14697580.2003.00213.x)

53 Bell LS, Kayser M \& Jones C. The mineralized osteocyte: a living fossil. American Journal of Physical Anthropology 2008137 449-456. (https://doi.org/10.1002/ajpa.20886)

54 Busse B, Djonic D, Milovanovic P, Hahn M, Püschel K, Ritchie RO, Djuric M \& Amling M. Decrease in the osteocyte lacunar density accompanied by hypermineralized lacunar occlusion reveals failure and delay of remodeling in aged human bone. Aging Cell 20109 1065-1075. (https://doi.org/10.1111/j.1474-9726.2010.00633.x)

55 Seeman E. Structural basis of growth-related gain and age-related loss of bone strength. Rheumatology 200847 (Supplement 4) iv2-iv8. (https://doi.org/10.1093/rheumatology/ken177)

56 Milovanovic P, Djuric M, Neskovic O, Djonic D, Potocnik J, Nikolic S, Stoiljkovic M, Zivkovic V \& Rakocevic Z. Atomic force microscopy characterization of the external cortical bone surface in young and elderly women: potential nanostructural traces of periosteal bone apposition during aging. Microscopy and Microanalysis 201319 1341-1349. (https://doi.org/10.1017/S1431927613001761)

57 Bellido T \& Plotkin LI. Novel actions of bisphosphonates in bone: preservation of osteoblast and osteocyte viability. Bone 201149 50-55. (https://doi.org/10.1016/j.bone.2010.08.008)

58 Plotkin LI, Lezcano V, Thostenson J, Weinstein RS, Manolagas SC $\&$ Bellido T. Connexin 43 is required for the anti-apoptotic effect of bisphosphonates on osteocytes and osteoblasts in vivo. Journal of Bone and Mineral Research 200823 1712-1721. (https://doi. org/10.1359/jbmr.080617)

59 Parfitt AM. Life history of osteocytes: relationship to bone age, bone remodeling, and bone fragility. Journal of Musculoskeletal and Neuronal Interactions 20022 499-500.

60 Seeman E. Age- and menopause-related bone loss compromise cortical and trabecular microstructure. Journals of Gerontology: Series A, Biological Sciences and Medical Sciences 201368 1218-1225. (https://doi.org/10.1093/gerona/glt071)

61 Tiede-Lewis LM, Xie Y, Hulbert MA, Campos R, Dallas MR, Dusevich V, Bonewald LF \& Dallas SL. Degeneration of the osteocyte network in the C57BL/6 mouse model of aging. Aging 20179 2190-2208. (https://doi.org/10.18632/aging.101308)

62 Hagan ML, Yu K, Zhu J, Vinson BN, Roberts RL, Montesinos Cartagena M, Johnson MH, Wang L, Isales CM, Hamrick MW, et al. Decreased pericellular matrix production and selection for enhanced cell membrane repair may impair osteocyte responses to mechanical loading in the aging skeleton. Aging Cell 202019 e13056. (https:// doi.org/10.1111/acel.13056)

63 Milovanovic P, Zimmermann EA, vom Scheidt A, Hoffmann B, Sarau G, Yorgan T, Schweizer M, Amling M, Christiansen S \& Busse B.
The formation of calcified Nanospherites during micropetrosis represents a unique mineralization mechanism in aged human bone. Small 201713 1602215. (https://doi.org/10.1002/smll.201602215)

64 Milovanovic P, vom Scheidt A, Mletzko K, Sarau G, Püschel K, Djuric M, Amling M, Christiansen S \& Busse B. Bone tissue aging affects mineralization of cement lines. Bone 2018110 187-193. (https://doi.org/10.1016/j.bone.2018.02.004)

65 Milovanovic P, Rakocevic Z, Djonic D, Zivkovic V, Hahn M, Nikolic S, Amling M, Busse B \& Djuric M. Nano-structural, compositional and micro-architectural signs of cortical bone fragility at the superolateral femoral neck in elderly hip fracture patients vs. healthy aged controls. Experimental Gerontology 201455 19-28. (https://doi. org/10.1016/j.exger.2014.03.001)

66 Bach-Gansmo FL, Brüel A, Jensen MV, Ebbesen EN, Birkedal H \& Thomsen JS. Osteocyte lacunar properties and cortical microstructure in human iliac crest as a function of age and sex. Bone 201691 11-19. (https://doi.org/10.1016/j.bone.2016.07.003)

67 Qiu S, Rao DS, Palnitkar S \& Parfitt AM. Age and distance from the surface but not menopause reduce osteocyte density in human cancellous bone. Bone 200231 313-318. (https://doi.org/10.1016/ s8756-3282(02)00819-0)

68 Milovanovic P \& Busse B. Inter-site variability of the human osteocyte lacunar network: implications for bone quality. Current Osteoporosis Reports 201917 105-115. (https://doi.org/10.1007/ s11914-019-00508-y)

69 Weinkamer R, Kollmannsberger P \& Fratzl P. Towards a connectomic description of the osteocyte lacunocanalicular network in bone. Current Osteoporosis Reports 201917 186-194. (https://doi. org/10.1007/s11914-019-00515-z)

70 Schneider P, Meier M, Wepf R \& Müller R. Towards quantitative 3D imaging of the osteocyte lacuno-canalicular network. Bone 201047 848-858. (https://doi.org/10.1016/j.bone.2010.07.026)

71 Rolvien T, Vom Scheidt A, Stockhausen KE, Milovanovic P, Djonic D, Hubert J, Hawellek T, Wacker A, Jebens V, Puschel K, et al. Inter-site variability of the osteocyte lacunar network in the cortical bone underpins fracture susceptibility of the superolateral femoral neck. Bone 2018112 187-193. (https://doi.org/10.1016/j. bone.2018.04.018)

72 Ashique AM, Hart LS, Thomas CDL, Clement JG, Pivonka P, Carter Y, Mousseau DD \& Cooper DML. Lacunar-canalicular network in femoral cortical bone is reduced in aged women and is predominantly due to a loss of canalicular porosity. Bone Reports 20177 9-16. (https://doi.org/10.1016/j.bonr.2017.06.002)

73 Tong X, Malo MKH, Burton IS, Jurvelin JS, Isaksson H \& Kröger H. Histomorphometric and osteocytic characteristics of cortical bone in male subtrochanteric femoral shaft. Journal of Anatomy $20172 \mathbf{2 1}$ 708-717. (https://doi.org/10.1111/joa.12670)

74 Akhter MP, Kimmel DB, Lappe JM \& Recker RR. Effect of macroanatomic bone type and estrogen loss on osteocyte lacunar properties in healthy adult women. Calcified Tissue International 2017 100 619-630. (https://doi.org/10.1007/s00223-017-0247-6)

75 Mullender MG, Tan SD, Vico L, Alexandre C \& Klein-Nulend J. Differences in osteocyte density and bone histomorphometry between men and women and between healthy and osteoporotic subjects. Calcified Tissue International 200577 291-296. (https://doi. org/10.1007/s00223-005-0043-6)

76 Mullender MG, Huiskes R, Versleyen H \& Buma P. Osteocyte density and histomorphometric parameters in cancellous bone of the proximal femur in five mammalian species. Journal of Orthopaedic Research 199614 972-979. (https://doi.org/10.1002/jor.1100140618)

77 Carpentier VT, Wong J, Yeap Y, Gan C, Sutton-Smith P, Badiei A, Fazzalari NL \& Kuliwaba JS. Increased proportion of hypermineralized osteocyte lacunae in osteoporotic and osteoarthritic human trabecular bone: implications for bone remodeling. Bone 201250 688-694. (https://doi.org/10.1016/j bone.2011.11.021)

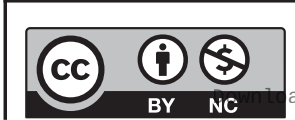

This work is licensed under a Creative Commons Attribution-NonCommercial 4.0 International License. ded from Bioscientifica com at 04/26/2023 10:14:23AM 
78 Power J, Noble BS, Loveridge N, Bell KL, Rushton N \& Reeve J. Osteocyte lacunar occupancy in the femoral neck cortex: an association with cortical remodeling in hip fracture cases and controls. Calcified Tissue International 200169 13-19. (https://doi. org/10.1007/s00223-001-0013-6)

79 Qiu S, Rao DS, Palnitkar S \& Parfitt AM. Reduced iliac cancellous osteocyte density in patients with osteoporotic vertebral fracture. Journal of Bone and Mineral Research 200318 1657-1663. (https://doi. org/10.1359/jbmr.2003.18.9.1657)

80 Weinbaum S, Cowin SC \& Zeng Y. A model for the excitation of osteocytes by mechanical loading-induced bone fluid shear stresses. Journal of Biomechanics 199427 339-360. (https://doi. org/10.1016/0021-9290(94)90010-8)

81 Knothe Tate ML. 'Whither flows the fluid in bone?' an osteocyte's perspective. Journal of Biomechanics 200336 1409-1424. (https://doi org/10.1016/s0021-9290(03)00123-4)

82 Hazenberg JG, Freeley M, Foran E, Lee TC \& Taylor D. Microdamage: a cell transducing mechanism based on ruptured osteocyte processes. Journal of Biomechanics 200639 2096-2103. (https://doi org/10.1016/j.jbiomech.2005.06.006)

83 Busse B, Bale HA, Zimmermann EA, Panganiban B, Barth HD, Carriero A, Vettorazzi E, Zustin J, Hahn M, Ager JW, et al. Vitamin D deficiency induces early signs of aging in human bone, increasing the risk of fracture. Science Translational Medicine 20135193 ra88. (https://doi.org/10.1126/scitranslmed.3006286)

84 Kuhn LT, Grynpas MD, Rey CC, Wu Y, Ackerman JL \& Glimcher MJ. A comparison of the physical and chemical differences between cancellous and cortical bovine bone mineral at two ages. Calcified Tissue International 200883 146-154. (https://doi.org/10.1007/ s00223-008-9164-z)

85 Milovanovic P, Potocnik J, Stoiljkovic M, Djonic D, Nikolic S, Neskovic O, Djuric M \& Rakocevic Z. Nanostructure and mineral composition of trabecular bone in the lateral femoral neck: implications for bone fragility in elderly women. Acta Biomaterialia 20117 3446-3451. (https://doi.org/10.1016/j.actbio.2011.05.028)

86 Paschalis EP, Betts F, DiCarlo E, Mendelsohn R \& Boskey AL. FTIR microspectroscopic analysis of normal human cortical and trabecular bone. Calcified Tissue International 199761 480-486. (https://doi. org/10.1007/s002239900371)

87 Tong W, Glimcher MJ, Katz JL, Kuhn L \& Eppell SJ. Size and shape of Mineralites in young bovine bone measured by atomic force microscopy. Calcified Tissue International 200372 592-598. (https:// doi.org/10.1007/s00223-002-1077-7)

88 Milovanovic P, Djuric M \& Rakocevic Z. Age-dependence of power spectral density and fractal dimension of bone mineralized matrix in AFM topography images: potential correlates of bone tissue age and bone fragility in female femoral neck trabeculae. Journal of Anatomy 2012221 427-433. (https://doi.org/10.1111/j.14697580.2012.01556.x)

89 Burr DB. Changes in bone matrix properties with aging. Bone 2019 120 85-93. (https://doi.org/10.1016/j.bone.2018.10.010)

90 Nyman JS, Roy A, Acuna RL, Gayle HJ, Reyes MJ, Tyler JH, Dean DD $\&$ Wang X. Age-related effect on the concentration of collagen crosslinks in human osteonal and interstitial bone tissue. Bone 2006 39 1210-1217. (https://doi.org/10.1016/j.bone.2006.06.026)

91 Thomas CJ, Cleland TP, Sroga GE \& Vashishth D. Accumulation of carboxymethyl-lysine (CML) in human cortical bone. Bone 2018110 128-133. (https://doi.org/10.1016/j.bone.2018.01.028)

92 Schmidt FN, Zimmermann EA, Campbell GM, Sroga GE, Püschel K, Amling M, Tang SY, Vashishth D \& Busse B. Assessment of collagen quality associated with non-enzymatic cross-links in human bone using Fourier-transform infrared imaging. Bone 201797 243-251. (https://doi.org/10.1016/j.bone.2017.01.015)

93 Wang X, Li X, Shen X \& Agrawal CM. Age-related changes of noncalcified collagen in human cortical bone. Annals of Biomedical Engineering 200331 1365-1371. (https://doi.org/10.1114/1.1623488)
94 Saito M \& Marumo K. Collagen cross-links as a determinant of bone quality: a possible explanation for bone fragility in aging, osteoporosis, and diabetes mellitus. Osteoporosis International 201021 195-214. (https://doi.org/10.1007/s00198-009-1066-z)

95 Rolvien T, Schmidt FN, Milovanovic P, Jähn K, Riedel C, Butscheidt S, Püschel K, Jeschke A, Amling M \& Busse B. Early bone tissue aging in human auditory ossicles is accompanied by excessive hypermineralization, osteocyte death and micropetrosis. Scientific Reports $2018 \mathbf{8}$ 1920. (https://doi.org/10.1038/s41598-01819803-2)

96 Thompson WR, Modla S, Grindel BJ, Czymmek KJ, Kirn-Safran CB, Wang L, Duncan RL \& Farach-Carson MC. Perlecan/Hspg2 deficiency alters the pericellular space of the lacunocanalicular system surrounding osteocytic processes in cortical bone. Journal of Bone and Mineral Research 201126 618-629. (https://doi.org/10.1002/ jbmr.236)

97 You LD, Weinbaum S, Cowin SC \& Schaffler MB. Ultrastructure of the osteocyte process and its pericellular matrix. Anatomical Record: Part A, Discoveries in Molecular, Cellular, and Evolutionary Biology 2004 278 505-513. (https://doi.org/10.1002/ar.a.20050)

98 Fritton SP \& Weinbaum S. Fluid and solute transport in bone: flow-induced mechanotransduction. Annual Review of Fluid Mechanics 200941 347-374. (https://doi.org/10.1146/annurev. fluid.010908.165136)

99 Tang SY, Herber RP, Ho SP \& Alliston T. Matrix metalloproteinase-13 is required for osteocytic perilacunar remodeling and maintains bone fracture resistance. Journal of Bone and Mineral Research 201227 1936-1950. (https://doi.org/10.1002/jbmr.1646)

100 Holmbeck K, Bianco P, Pidoux I, Inoue S, Billinghurst RC, Wu W, Chrysovergis K, Yamada S, Birkedal-Hansen H \& Poole AR. The metalloproteinase MT1-MMP is required for normal development and maintenance of osteocyte processes in bone. Journal of Cell Science 2005118 147-156. (https://doi.org/10.1242/jcs.01581)

101 Plotkin LI \& Bellido T. Osteocytic signalling pathways as therapeutic targets for bone fragility. Nature Reviews: Endocrinology 201612 593-605. (https://doi.org/10.1038/nrendo.2016.71).

102 Eidelman N, Chow LC \& Brown WE. Calcium phosphate saturation levels in ultrafiltered serum. Calcified Tissue International 198740 71-78. (https://doi.org/10.1007/bf02555708)

103 Price PA \& Lim JE. The inhibition of calcium phosphate precipitation by fetuin is accompanied by the formation of a fetuin-mineral complex. Journal of Biological Chemistry 2003278 22144-22152. (https://doi.org/10.1074/jbc.M300744200)

104 Andrukhova O, Schüler C, Bergow C, Petric A \& Erben RG. Augmented fibroblast growth factor- 23 secretion in bone locally contributes to impaired bone mineralization in chronic kidney disease in mice. Frontiers in Endocrinology 20189 311. (https://doi. org/10.3389/fendo.2018.00311)

105 Bertazzo S, Gentleman E, Cloyd KL, Chester AH, Yacoub MH \& Stevens MM. Nano-analytical electron microscopy reveals fundamental insights into human cardiovascular tissue calcification. Nature Materials 201312 576-583. (https://doi.org/10.1038/ nmat3627)

106 Reynolds JL, Joannides AJ, Skepper JN, McNair R, Schurgers LJ, Proudfoot D, Jahnen-Dechent W, Weissberg PL \& Shanahan CM. Human vascular smooth muscle cells undergo vesicle-mediated calcification in response to changes in extracellular calcium and phosphate concentrations: a potential mechanism for accelerated vascular calcification in ESRD. Journal of the American Society of Nephrology 200415 2857-2867. (https://doi.org/10.1097/01. ASN.0000141960.01035.28)

107 Proudfoot D, Skepper JN, Hegyi L, Bennett MR, Shanahan CM \& Weissberg PL. Apoptosis regulates human vascular calcification in vitro: evidence for initiation of vascular calcification by apoptotic bodies. Circulation Research 200087 1055-1062. (https://doi. org/10.1161/01.res.87.11.1055)

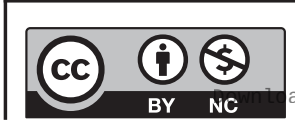


108 Shah FA, Lee BEJ, Tedesco J, Larsson Wexell C, Persson C, Thomsen P, Grandfield K \& Palmquist A. Micrometer-sized magnesium whitlockite crystals in micropetrosis of bisphosphonate-exposed human alveolar bone. Nano Letters 201717 6210-6216. (https://doi. org/10.1021/acs.nanolett.7b02888)

109 Fernández-Segura E, Cañizares FJ, Cubero MA, Warley A \& Campos A. Changes in elemental content during apoptotic cell death studied by electron probe X-ray microanalysis. Experimental Cell Research 1999 253 454-462. (https://doi.org/10.1006/excr.1999.4657)

110 Kirsch T, Wang W \& Pfander D. Functional differences between growth plate apoptotic bodies and matrix vesicles. Journal of Bone and Mineral Research 200318 1872-1881. (https://doi.org/10.1359/ jbmr.2003.18.10.1872)

111 Kapustin AN, Davies JD, Reynolds JL, McNair R, Jones GT, Sidibe A, Schurgers LJ, Skepper JN, Proudfoot D, Mayr M, et al. Calcium regulates key components of vascular smooth muscle cell-derived matrix vesicles to enhance mineralization. Circulation Research 2011 109 e1-e12. (https://doi.org/10.1161/CIRCRESAHA.110.238808)

112 Marino G \& Kroemer G. Mechanisms of apoptotic phosphatidylserine exposure. Cell Research 201323 1247-1248. (https://doi.org/10.1038/cr.2013.115)

113 Weinstein RS, Jilka RL, Parfitt AM \& Manolagas SC. Inhibition of osteoblastogenesis and promotion of apoptosis of osteoblasts and osteocytes by glucocorticoids. Potential mechanisms of their deleterious effects on bone. Journal of Clinical Investigation $1998 \mathbf{1 0 2}$ 274-282. (https://doi.org/10.1172/JCI2799)

114 Fowler TW, Acevedo C, Mazur CM, Hall-Glenn F, Fields AJ, Bale HA, Ritchie RO, Lotz JC, Vail TP \& Alliston T. Glucocorticoid suppression of osteocyte perilacunar remodeling is associated with subchondral bone degeneration in osteonecrosis. Scientific Reports 2017744618. (https://doi.org/10.1038/srep44618)

115 Jilka RL, Noble B \& Weinstein RS. Osteocyte apoptosis. Bone 201354 264-271. (https://doi.org/10.1016/j.bone.2012.11.038)

116 Weinstein RS, Jilka RL, Almeida M, Roberson PK \& Manolagas SC. Intermittent parathyroid hormone administration counteracts the adverse effects of glucocorticoids on osteoblast and osteocyte viability, bone formation, and strength in mice. Endocrinology 2010 151 2641-2649. (https://doi.org/10.1210/en.2009-1488)

117 Chandra A, Lin T, Tribble MB, Zhu J, Altman AR, Tseng WJ, Zhang Y, Akintoye SO, Cengel K, Liu XS, et al. PTH1-34 alleviates radiotherapy-induced local bone loss by improving osteoblast and osteocyte survival. Bone 201467 33-40. (https://doi.org/10.1016/j. bone.2014.06.030)

118 Rolvien T, Krause M, Jeschke A, Yorgan T, Puschel K, Schinke T, Busse B, Demay MB \& Amling M. Vitamin D regulates osteocyte survival and perilacunar remodeling in human and murine bone. Bone 2017103 78-87. (https://doi.org/10.1016/j. bone.2017.06.022)

Received in final form 24 February 2020

Accepted 13 March 2020

Accepted Manuscript published online 13 March 2020 https://ec.bioscientifica.com

https://doi.org/10.1530/EC-19-0531 (c) 2020 The authors Published by Bioscientifica Ltd
This work is licensed under a Creative Commons Attribution-NonCommercial 4.0 International License. ded from Bioscientifica com at 04/26/2023 10:14:23AM 